\title{
Analisis Multi-Atribut dan Jaringan Syaraf Tiruan dengan Optimalisasi Filter untuk Deteksi Patahan Penampang Seismik Lapangan F3 Laut Utara Belanda
}

\author{
Melanz Hasan*, Elistia Liza Namigo \\ Laboratorium Fisika Bumi, Jurusan Fisika FMIPA Universitas Andalas \\ Kampus Unand, Limau Manis, Padang, 25163 \\ *melanzhasan@gmail.com
}

\begin{abstract}
ABSTRAK
Identifikasi patahan merupakan salah satu langkah awal dalam interpretasi seismik dan menjadi komponen penting dalam pengembangan strategi eksplorasi. Deteksi patahan dilakukan dengan metode analisis multi-atribut dan jaringan syaraf tiruan (JST). Metode ini diterapkan pada data blok F3 Sektor Laut Utara Belanda. Atribut seismik yang digunakan sebagai data masukan terdiri dari similarity, spectral decomposition, curvature, dip dan semblance. Pickset yang digunakan pada penelitian ini terdiri dari pickset pada patahan besar dan patahan kecil dengan jumlah 400 pick. Data latih yang digunakan pada pelatihan JST adalah penampang seismik pada inline 325. Penampang seismik yang digunakan sebagai data uji adalah inline 256 dan 272. Hasil pelatihan JST dengan kombinasi multi-atribut similarity, spectral decomposition dan semblance menunjukan efektifitas yang paling tinggi untuk deteksi patahan. Pelatihan JST pada patahan besar secara visual menghasilkan kualitas deteksi yang lebih baik dibandingkan dengan patahan kecil. Penerapan fault enhancement filter (FEF) menghasilkan penampang seismik yang lebih tajam sehingga mempermudah proses picking dan menghasilkan pelatihan JST yang lebih baik dengan nilai error lebih kecil. Pickset yang sudah dilatih pada inline 325 dapat diterapkan pada data uji dengan probabilitas patahan yang makin jelas dan tajam dengan nilai misclassification error $2,56 \%$.
\end{abstract}

Kata kunci: deteksi patahan, jaringan syaraf tiruan, analisis atribut

\section{ABSTRACT}

Fault identification is one of the first steps in seismic interpretation and becomes an important component in the development of exploration strategies. Fault detection was carried out by combination of multi-attribute analysis method and artificial neural network (ANN). This method had been performed on a seismic section of F3 Block, North Sea of Netherlands. Seismic attributes used as input data consist of similariy, spectral decomposition, curvature, dip and semblance. The pickset used in this study consisted of pickets on large fault and small fault with 400 picks. The training data used in the ANN training was inline 325. Seismic inline used as test data were inline 256 and 272. The results show the highest effectiveness for fault detection resulted in ANN training with a combination of similarity, spectral decomposition and semblance attributes. ANN training on large faults visually produces better detection quality compared to small faults. Fault enhancement filter (FEF) produced a sharper seismic cross section used in the picking process and a better ANN training with a smaller error value. Picksets that have been trained on inline 325 were applied to test data resulted to clearer and sharper fault probability with misclassification value of $2.56 \%$.

Keywords: fault detection, artificial neural network, attributes analysis

\section{PENDAHULUAN}

Patahan di bawah permukaan dapat menjadi penghalang dalam migrasi hidrokarbon dan dapat juga berfungsi sebagai perangkap hidrokarbon (Zhang dkk, 2014). Identifikasi patahan merupakan salah satu langkah awal dalam interpretasi seismik dan menjadi komponen penting dalam pengembangan strategi eksplorasi migas. Menurut Meldhal dan Heggland (2001) metode yang digunakan untuk mendeteksi patahan adalah metode konvensional dan metode atribut seismik.

Metode konvensional dilakukan dengan cara picking manual untuk melihat anomali pada kontinuitas pada penampang seismik. Metode ini hanya bisa diaplikasikan untuk mengidentifikasi patahan yang berukuran besar. Metode deteksi patahan lain yang digunakan yaitu metode analisis atribut. Pada metode ini, deteksi patahan dilakukan dengan cara menggunakan informasi yang diperoleh dari atribut seismik. Atribut seismik adalah segala informasi baik yang terukur, terhitung, dan tersirat dalam data seismik (Thapar, 2004). Zheng dkk (2013) menyatakan bahwa metode analisis atribut seismik berkontribusi dalam interpretasi 
seismik 3D. Metode ini mampu meningkatkan informasi geologi yang sulit dilakukan dengan metode konvensional (Ayolabi dan Adigun, 2013).

Seismik atribut terdiri dari beberapa atribut yang sensitif terhadap patahan diantaranya curvature, similarity, dip, spectral decomposition dan semblance. Zheng dkk (2013) mengatakan curvature dan similarity dapat meningkatkan resolusi pencitraan dan memperlihatkan dengan jelas kontinuitas pada patahan. Atribut lain yang juga sensitif terhadap patahan adalah spectral decomposition. Pengunaan atribut ini juga meningkatkan resolusi seismik dan memperlihatkan patahan yang tidak dikenali oleh atribut lain. Hasil penelitian Zheng dkk (2013) menjelaskan bahwa penggunaan satu atribut saja masih belum sempurna dalam mendeteksi patahan. Hal itu disebabkan, tidak ada satu atribut yang mampu mengidentifikasi satu objek secara sempurna. Untuk itu diperlukan beberapa kombinasi atribut (multi-atribut) untuk meningkatkan kualitas deteksi objek yang sama (Tingdahl dan Rooij, 2005).

Menurut Brouwer dkk (2011) metode kombinasi multi-atribut dan jaringan syaraf tiruan (JST) adalah metode yang paling efisien. Penggunaan multi-atribut dan JST akan menghasilkan atribut baru yang mampu menggambarkan probabilitas patahan dalam volume seismik (Meldhal dan Heggland, 2001). JST mampu meningkatkan kualitas interpretasi geologi pada data seismik. Metode ini sangat efektif dalam menggambarkan patahan pada penampang seismik. Selain itu, metode ini menghasilkan pencitraan dengan meminimalisir noise sehingga objek terlihat lebih jelas (Zheng dkk, 2013).

Penelitian deteksi patahan dengan metode kombinasi multi-atribut dan JST telah banyak dilakukan. Salah satunya Lestari (2017) menggunakan kombinasi atribut curvature, similarity, dip dan spectral decomposition untuk mendeteksi patahan pada lapangan F3 laut utara Belanda. Penelitian tersebut menyimpulkan penambahan jumlah pick dan penambahan atribut yang dikombinasikan akan meningkatkan kualitas deteksi patahan.

Pada penelitian ini, akan dilakukan deteksi patahan pada data seismik 2D F3 laut Utara Belanda menggunakan software OpendTect. Penelitian ini bertujuan untuk menguji efektifitas masing-masing atribut dan juga multi-attribut pada pelatihan JST. Jumlah pick pada penelitian ini ditingkatkan menjadi 400 pick. Atribut yang digunakan adalah similarity, spectral decomposition, curvature dan dip. Penambahan atribut semblance juga akan digunakan untuk menghasilkan probabilitas patahan yang lebih baik. Atribut semblance menunjukan diskontinuitas yang jelas pada penampang seismik (Marfurt dkk, 1999). Optimalisasi juga dilakukan pada penelitian ini dengan menggunakan fault enchancement filter (FEF). Filter ini berfungsi untuk memperjelas kontinuitas pada penampang seismik (Zheng dkk, 2013).

\section{METODE}

\subsection{Data}

Gambar 1 adalah peta lokasi Lapangan F3 sektor laut utara Belanda. Data Lapangan F3 ini dipilih karena pada penampang seismiknya terlihat adanya patahan berukuran besar dan juga kecil (Lawal dkk, 2016). Inline range pada data seismik ini yaitu $100-750$. Inline yang dipilih untuk data latih adalah inline 325. Wang dkk (2014) mengatakan patahan terdapat pada lapangan F3 terutama pada rentang inline 199 sampai 349. Selain itu, secara visual patahan terlihat jelas pada inline 325. Data uji yang digunakan adalah inline 256 dan 272. Kedua inline ini dipilih karena secara visual terlihat adanya kontinuitas yang rendah pada penampang seismiknya (Lawal dkk, 2016). Atribut seismik digunakan sebagai data masukan pada pelatihan JST. Atribut yang digunakan pada penelitian ini yaitu similarity, spectral decomposition, curvature, dip dan semblance. Optimalisasi juga dilakukan dengan menggunakan fault enhancement filter untuk menghasilkan pencitraan yang lebih bagus dan memudahkan proses picking.

\subsection{Pengolahan Data}

Deteksi patahan dihasilkan dari pengolahan atribut seismik dengan menggunakan metode pelatihan JST pada software OpendTect. Proses pengolahan data pada OpendTect dilakukan dengan menggunakan window dan icon perintah yang terintegrasi. JST telah 
diintegrasikan dengan algoritma backpropagation dengan tipe pelatihan terawasi. Pelatihan terawasi merupakan metode pelatihan dengan nilai keluaran yang diharapkan telah diketahui sebelumnya. Keluaran yang diharapkan berupa patahan dan bukan patahan. keluaran berupa patahan dan bukan patahan diperoleh dari hasil picking. Tahapan dalam pengolahan data dilakukan dengan langkah sebagai berikut:

1. Pelatihan JST pada atribut tunggal. Pada tahapan ini pelatihan JST dilakukan pada daerah latih dengan menggunakan atribut tunggal. Tahapan ini bertujuan untuk melihat efektifiatas masing-masing atribut dalam mendeteksi patahan dilihat dari probabilitas patahan secara visual dan nilai misclassification error.

2. Pelatihan JST kombinasi multi-atribut. Kombinasi multi-atribut yang digunakan adalah lima atribut dan tiga atribut. Kombinasi atribut dilatih pada daerah latih untuk melihat kombinasi atribut yang paling baik dalam mendeteksi patahan.

3. Penerapan FEF pada pelatihan JST kombinasi multi-atribut. Hasil deteksi patahan kombinasi multi-atribut yang paling baik ditingkatkan dengan menggunakan FEF pada pelatihan JST.

4. Penerapan JST pada data uji. Pada tahap ini hasil pelatihan JST diterapkan pada inline yang berbeda untuk melihat keefektifan pelatihan dalam mendeteksi patahan.

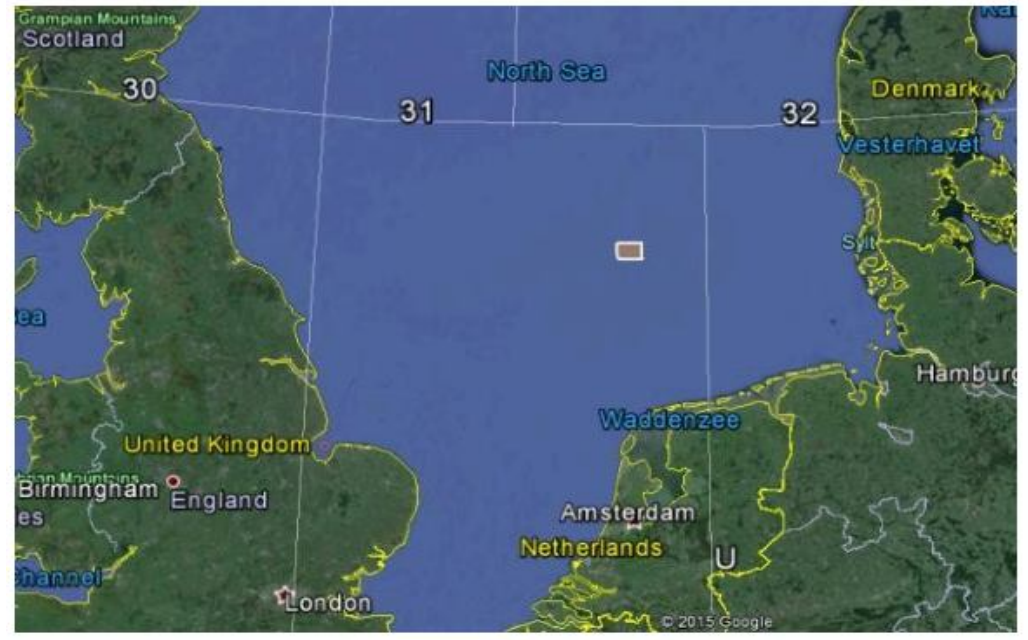

Gambar 1 Lokasi blok F3 sektor laut utara Belanda

\section{HASIL DAN DISKUSI}

\subsection{Pelatihan JST pada Atribut Tunggal pada Inline 325}

Gambar 2 memperlihatkan probabilitas patahan hasil pelatihan JST pada atribut tunggal. Pelatihan JST ini menggunakan pickset patahan besar dengan jumlah 400 pick. Kombinasi atribut seismik dengan JST akan menentukan kualitas deteksi suatu objek pada penampang seismik. Hal ini dikarenakan setiap atribut seismik memiliki respon yang berbeda terhadap anomali bawah permukaan seperti patahan.

Gambar 2a dan 2b memperlihatkan hasil keluaran pelatihan JST pada atribut similarity dan spectral decomposition. Probabilitas patahan ditunjukan oleh warna biru. Daerah yang diberi lingkaran hitam merupakan daerah yang terindikasi sebagai patahan. Kedua hasil pelatihan JST ini memperlihatkan adanya probabilitas patahan. Hasil pada daerah 3 setelah dilakukan pelatihan JST memperlihatkan adanya probabilitas patahan yang terlihat jelas dan tegas. Hasil keluaran pada daerah 1, 2, dan 4 juga memperlihatkan adanya probabilitas patahan, namun patahan yang terdeteksi tidak lebih jelas dibandingkan daerah 3. Atribut spectral decomposition memperlihatkan anomali kemenerusan yang lebih jelas dibandingkan atribut similarity. Nilai misclassification percentage yang diperoleh untuk pelatihan atribut similarity dan spectral decomposition secara berurutan adalah 20,00\% dan 47,19\%.

Gambar 2c dan 2d memperlihatkan hasil keluaran pelatihan JST pada atribut curvature dan dip. Kedua atribut ini menghasilkan probabilitas patahan yang tidak jelas dibandingkan 
atribut yang lain. Nilai misclassification percentage yang diperoleh untuk pelatihan atribut curvature dan dip berurut adalah $46,59 \%$ dan $36,14 \%$.

Gambar 2e merupakan keluaran pelatihan JST pada atribut semblance. Daerah yang terindikasi patahan ditandai dengan lingkaran hitam. Hasil pelatihan ini menghasilkan probabilitas patahan yang jelas. Probabilitas patahan yang paling terlihat jelas terdapat pada daerah 3. Hasil pada daerah ini menggambarkan patahan dengan tegas. Nilai misclassification percentage yang diperoleh dari pelatihan ini adalah $15,79 \%$.

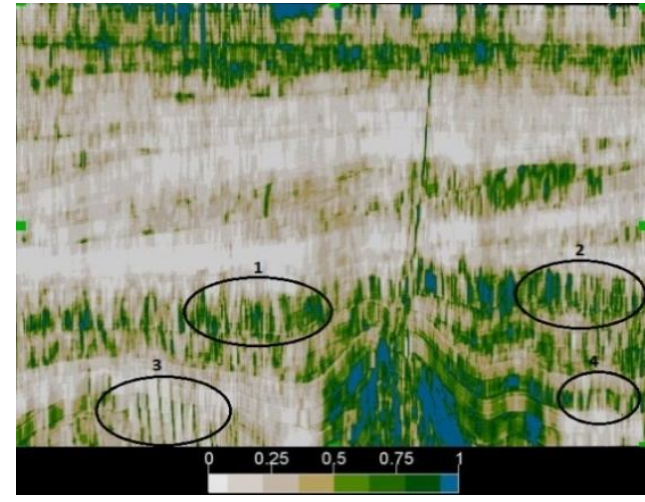

(a)

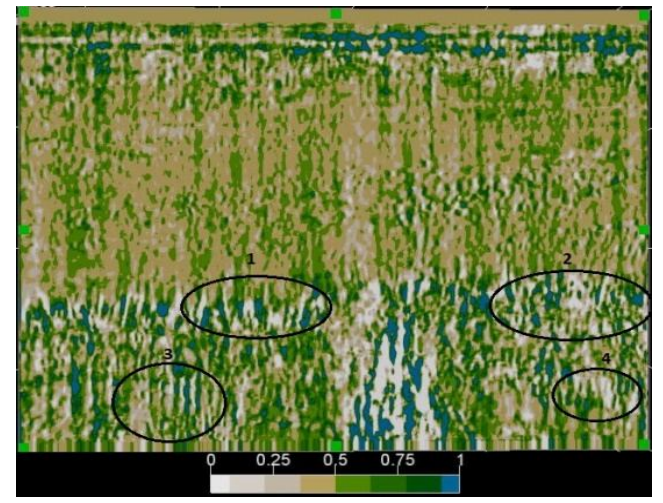

(c)

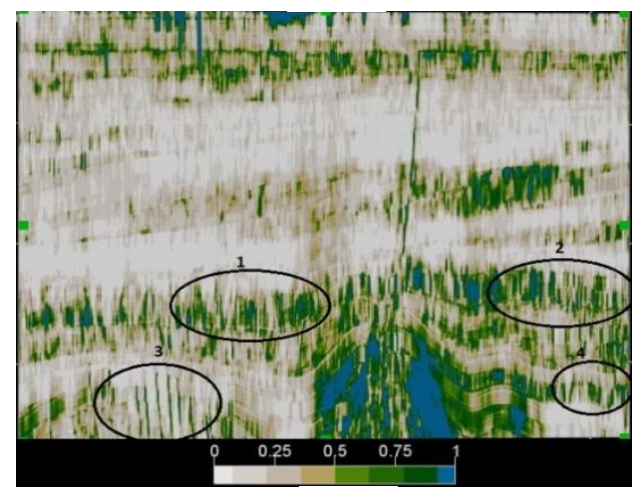

(e)

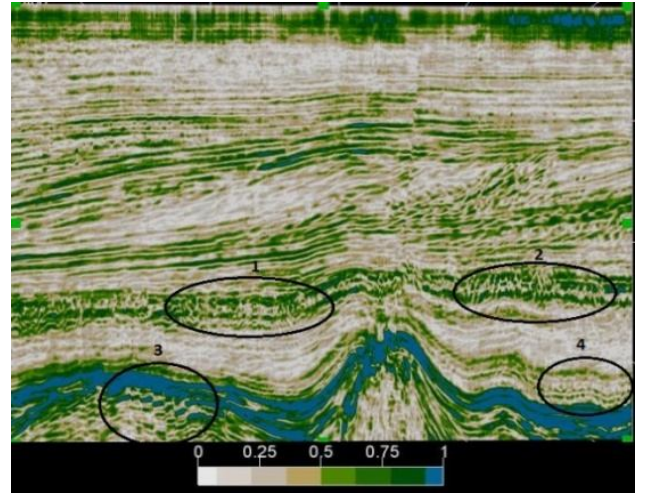

(b)

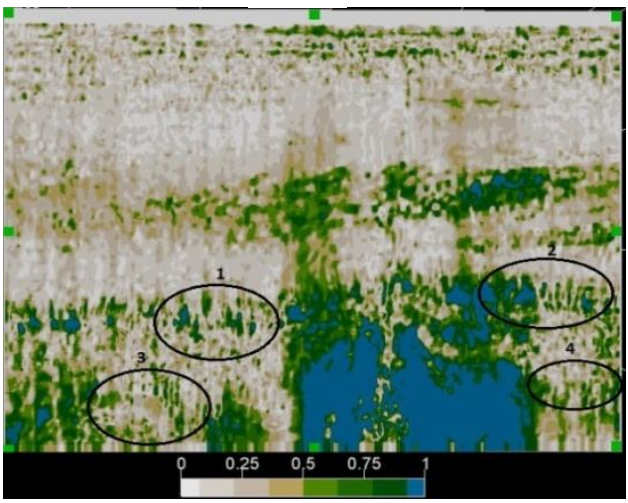

(d)

Gambar 2 Hasil pelatihan JST satu atribut pada inline 325 (a) similarity (b) spectral decomposition (c) curvature (d) dip (e) semblance

Berdasarkan hasil yang telah diperoleh diatas, dapat disimpulkan bahwa dari atribut similarity, spectral decomposition dan semblance dapat mendeteksi patahan. Atribut spectral decomposition secara khusus, menampilkan kemenerusan yang lebih baik pada penampang seismik sehingga anomali pada kemeneruan tersebut (berupa patahan) lebih mudah untuk diidentifikasi. Sementara pelatihan JST dengan atribut curvature dan dip tidak sensitif terhadap 
patahan. Hal ini dilihat sulitnya melihat adanya probabilitas patahan dari penampang seismik hasil keluaran.

\subsection{Pelatihan JST pada Kombinasi Atribut pada Inline 325}

Pelatihan JST dengan kombinasi beberapa atribut diharapkan mampu menghasilkan deteksi patahan yang lebih akurat. Atribut yang dikombinasikan berupa kombinasi lima atribut dan tiga atribut. Gambar 3 merupakan keluaran pelatihan JST kombinasi atribut.

Gambar 3a merupakan hasil pelatihan JST dengan kombinasi lima atribut. Atribut yang digunakan adalah similarity, spectral decomposition, curvature, dip dan semblance. Pelatihan JST kombinasi lima atribut menghasilkan kualitas deteksi patahan yang semakin baik. Pada daerah 3 terlihat probabilitas patahan yang jelas dan tegas. Hal yang sama juga dapat dilihat pada daerah 4. Pada daerah 1 dan 2 juga teridentifikasi adanya patahan namun patahan yang telihat masih belum jelas dikarena probabilitas patahan masih terlihat menumpuk. Pelatihan JST ini juga menghasilkan nilai misclassification percentage kecil yaitu $6,90 \%$.

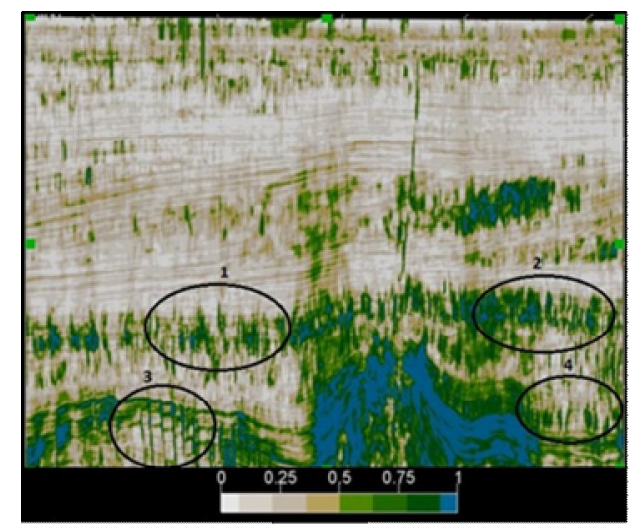

(a)

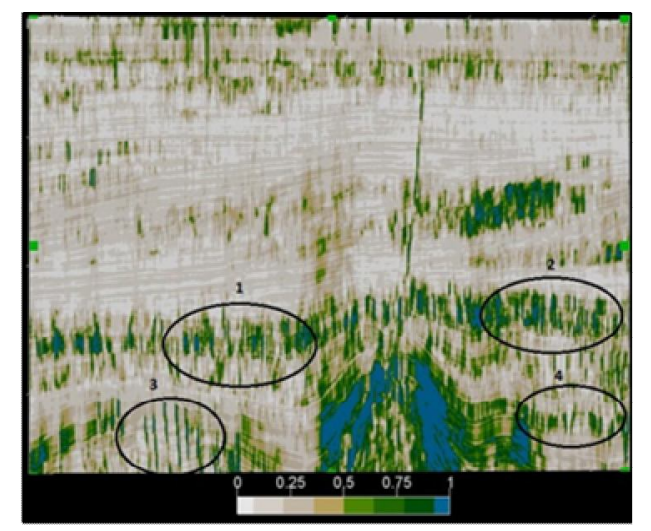

(b)

Gambar 3 Hasil pelatihan JST kombinasi atribut (a) lima atribut (b) tiga atribut

Hasil pelatihan JST pada atribut curvature dan dip tidak memberikan keluaran yang bisa digunakan untuk mendeteksi patahan. Hal ini mendorong untuk dilakukannya pelatihan JST dengan kombinasi tiga atribut yaitu similarity, spectral decomposition dan semblance. Gambar 3b merupakan hasil pelatihan JST dengan kombinasi tiga atribut. Probabilitas patahan yang dihasilkan pada pelatihan JST tiga atribut lebih baik dibandingkan dengan lima atribut. Penumpukan pada daerah 1, 2 dan 4 terlihat berkurang namun patahan masih belum bisa dideteksi dengan jelas. Hal ini terjadi dikarenakan adanya kemungkinan pada daerah 1, 2 dan 4 terdapat patahan lebih kecil yang memiliki resolusi jauh dibawah resolusi seismik. Nilai misclassification percentage yang diperoleh $4,35 \%$.

\subsection{Penerapan FEF pada Pelatihan JST Kombinasi Atribut pada Inline 325}

Pelatihan JST pada kombinasi atribut dioptimalisasi dengan menggunakan FEF. Penerapan FEF pada pelatihan JST yang dikombinasikan dengan atribut diharapkan dapat menghasilkan probabilitas patahan yang lebih baik pada penampang seismik. Pickset yang digunakan pickset patahan besar. Hasil penerapan FEF pada pelatihan JST kombinasi atribut terlihat pada Gambar 4.

Kombinasi atribut yang digunakan adalah similarity, spectral decomposition dan semblance. Penerapan FEF pada pelatihan JST ini menghasilkan probabilitas patahan yang lebih baik dibandingkan tanpa menggunakan FEF. Daerah 3 dapat dilihat probabilitas patahan yang lebih jelas dan tegas. Daerah 1, 2 dan 4 juga terdeteksi adanya patahan. Penumpukan pada 1, 2 dan 4 terlihat berkurang pada namun patahan masih belum bisa dideteksi dengan jelas. Nilai misclassification percentage yang diperoleh lebih kecil sebesar $2,56 \%$. 


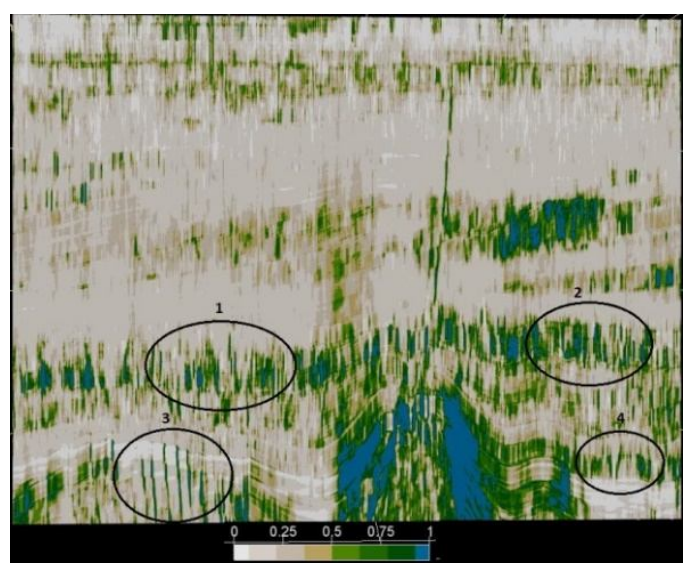

Gambar 4 Hasil Penerapan FEF pada pelatihan JST kombinasi tiga atribut inline 325

\subsection{Penerapan Pickset yang Sudah Dilatih pada Penampang Seismik Berbeda}

Hasil pelatihan JST kombinasi tiga atribut yang telah diperoleh sebelumnya diterapkan pada penampang seismik yang lain. Pengujian ini bertujuan untuk melihat efektifitas hasil pelatihan JST. Penerapan hasil pelatihan JST kombinasi multi-atribut diharapkan mampu menghasilkan pencitraan yang lebih baik untuk mendeteksi patahan. Atribut yang digunakan yaitu similarity, spectral decomposition dan semblance. Ketiga atribut ini terbukti menghasilkan keluaran dengan probabilitas patahan yang baik Penampang seismik yang digunakan sebagai data uji adalah inline 256 dan inline 272. Kedua inline ini dipilih karena secara visual dapat dilihat adanya anomali kemenerus berupa patahan. Gambar 5 merupakan keluaran untuk penerapan JST.

Gambar 5a merupakan hasil penerapan JST kombinasi tiga atribut pada penampang seismik 2D inline 256. Penerapan JST menghasilkan probabilitas patahan yang lebih jelas. Daerah 1 terlihat adanya patahan besar yang jelas dan tegas. Hal yang sama juga terlihat pada Daerah 4. Patahan berukuran kecil terdeteksi pada Daerah 4. Daerah 2, 3 dan 5 juga menghasilkan probabilitas patahan, namun patahan yang terlihat belum tergambar jelas dan tegas.

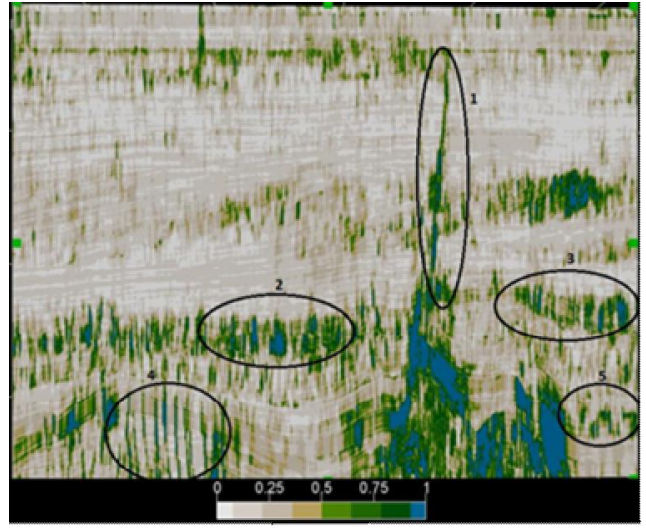

(a)

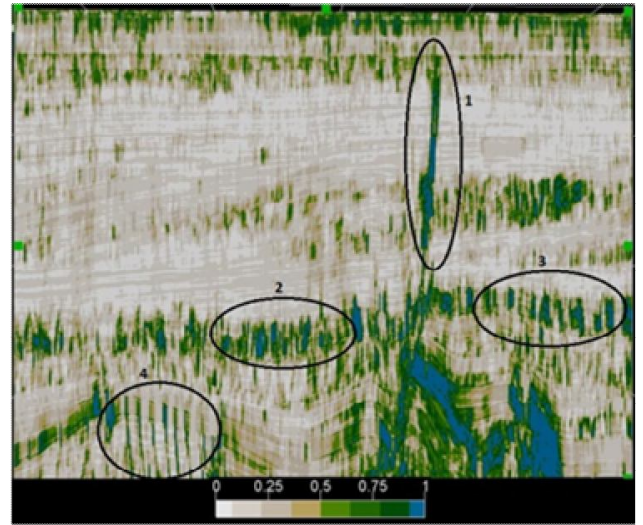

(b)

Gambar 5 Hasil penerapan JST (a) inline 256 (b) inline 272

Gambar 5b hasil Penerapan JST yang terlihat pada menghasilkan probabilitas patahan yang baik. Pada daerah 1 terdeteksi adanya patahan besar yang tegas dan jelas. Patahan berukuran kecil juga terdeteksi pada daerah 4 . Pada daerah 2 dan 3 juga terlihat adanya probabilitas patahan, namun patahan yang terdeteksi belum begitu jelas dan tegas. Probabilitas patahan pada dua daerah tersebut terlihat masih menumpuk.

Hasil pelatihan JST dengan kombinasi tiga (atribut similarity, spectral decomposition dan semblance) dapat diterapkan pada inline yang berbeda. Hasil penerapan ini memperlihatkan 
bahwa kombinasi atribut similarity, spectral decomposition dan semblance memberikan efektifitas yang baik dalam mendeteksi patahan.

\section{KESIMPULAN}

Berdasaran hasil penelitian yang diperoleh dapat disimpulkan identifikasi patahan dengan menggunakan atribut similarity, spectral decomposition dan semblance menghasilkan deteksi patahan yang cukup baik dibandingkan dengan atribut curvature dan dip. Pelatihan JST dengan menggunakan kombinasi tiga atribut (similarity, spectral decomposition dan semblance) menghasilkan probabilitas patahan yang lebih baik dibandingkan dengan kombinasi lima atribut (similarity, spectral decomposition, curvature, dip dan semblance). 4. Penerapan FEF pada pelatihan JST menghasilkan penampang seismik dengan anomali patahan yang jelas dengan nilai misclassification error $2,56 \%$. Pickset yang sudah dilatih pada inline 325 dapat diterapkan pada inline seismik yang lain dengan hasil probabilitas patahan yang cukup baik.

\section{DAFTAR PUSTAKA}

Ayolabi, E.A. dan Adigun, O.A., The Use of Seismic Attributes to Enhance Structural Interpretation of Z-Field Onshore Niger Delta, Earth Science Research, Canadian Center of Science and Education, (2013)

Brouwer, F.C.G., Connolly, D., dan Tingahl, K., A Guide to The Practical Use of Neural Networks, $d G B$ Earth Science, USA, (2011)

Lawal, A., Al-Dharrab, S., Deriche, M., Shafiq, M.A., dan Al-Regib, G., Fault Detection Using Seismic Attributes and Visual Saliency, SEG International Exposition and 86th Annual Meeting, hal. 1939 - 1943, (2016)

Lestari, E., Deteksi Patahan pada Penampang Seismik Lapangan F3 Laut Utara Belanda Menggunakan Analisis Atribut dan Jaringan Syaraf Tiruan, Skripsi, Jurusan Fisika, Unand, Padang, 2017

Marfurt, K. J., V. Sudhaker, A. G, K. D. Crawford, dan S. E. Nissen., Coherency calculations in the presence of structural dip, Geophysics, Vol. 64, hal. 104-111, (1999)

Meldahl, P., dan Heggland, R., Indentifying Fault and Gas Chimneys Using Multi-Attribute and Neural Network, The Leading Egde, Vol. 20, P.1050, (2001)

Thapar, M.R., Seismic Atribute Principal and Aplication, Petro Skills, 2004, hal.73-123.

Tingdahl, K.M., dan Rooij, M., Semi-automatic Detection of Faults in 3D Seismic Data, Geophysical Prospecting, hal.533-542, (2005)

Zhang, Bo., Liu, Y., Pelissier, M. dan Hemstra, N., Semiautomatied Fault Interpretation Based on Seismic Attributes, Interpretation, Vol. 2, Oklahoma, (2014)

Zheng, Z., Kavousi, P., dan Di, H., Multi-Attributea and Neural Network-Based Fault Detection in 3D Seismic Interpretation, Trans Tech Publication, Swizerland, (2013) 